\title{
Increased Organic Matter in the Growing Medium Decreases Benlate DF Phytotoxicity
}

\author{
M. W. van Iersel, Department of Horticulture, Georgia Experiment Station, Griffin 30223-1797, and B. Bugbee, \\ Department of Plants, Soils, and Biometeorology, Utah State University, Logan 84322-4820
}

\begin{abstract}
van Iersel, M. W., and Bugbee, B. 1997. Increased organic matter in the growing medium decreases Benlate DF phytotoxicity. Plant Dis. 81:743-748.

Some benzimidazole fungicides are phytotoxic to bedding plants. Organic pesticides are bound to the organic matter fraction in the root zone and their availability to plants depends on the composition of the growing medium. Thus, pesticide phytotoxicity may be affected by the fraction of organic matter in the growing medium. We conducted two studies to examine the relationship between benzimidazole phytotoxicity and organic matter content of the growing medium. In the first study, plants were grown in diatomaceous earth, containing no organic matter, and drenched with different fungicides. Benlate DF reduced carbon accumulation (growth) of the plants by 32 and $73 \%$ at the $0.5 \times$ and $1 \times$ label rate, respectively. Carbon gain of plants drenched with either Derosal or 3336 WP was similar to that of the control plants. Both Benlate DF and 3336 WP significantly decreased the number of flowers on the plants. The second study quantified the phytotoxicity of Benlate DF in media containing different amounts of organic matter. The growth of Benlate DF-treated plants was strongly affected by the amount of peat. Net photosynthesis decreased and the severity of visual symptoms (chlorosis) of Benlate DF phytotoxicity increased in media containing less peat. Benlate DF phytotoxicity strongly depends on the amount of organic matter in the growing medium, probably due to sorption of the active ingredient of Benlate DF and/or its breakdown products to the organic matter.
\end{abstract}

Some benzimidazole fungicides can reduce photosynthesis and cause visual symptoms in a variety of bedding plants (26). The decreased photosynthesis for 7 to 10 days after the application of Benlate DF was associated with dibutylurea (DBU), a product of the chemical breakdown of the active ingredient in Benlate, benomyl (methyl 1-[butylcarbamoyl]-2-benzimidazole-carbamate) (27). The decrease in photosynthesis was closely related to the amount of DBU applied to the plants. Environmental factors may affect DBU availability to plant roots, thereby influencing the phytotoxicity of Benlate DF. Benlate DF was removed from the market in 1991, but interest remains in its phytotoxicity and that of its active ingredient, benomyl. Benomyl is still available in the wettable powder formulation, Benlate WP, which has similar phytotoxic properties as Benlate DF (26).

Corresponding author: M. W. van Iersel E-mail: mvanier@gaes.griffin.peachnet.edu

Mention of brand names is for information only and does not constitute an endorsement to the exclusion of other products that might also be suitable.

Approved as journal paper no. 4964.

Accepted for publication 20 March 1997.

Publication no. D-1997-0424-06R

(C) 1997 The American Phytopathological Society
Plant uptake of benomyl, or its fungitoxic breakdown products, can be affected by the composition of the growing medium. Benomyl uptake was greatest by plants grown in sand, less in soil, and least by plants grown in a mixture of soil, peat, and perlite (1:2:2) (8). A similar uptake pattern occurred in plants grown in soil and sand (29). Subsequent work showed that maximum accumulation of fungitoxicant occurred in seedlings grown in media with the lowest amount of organic matter and highest $\mathrm{pH}$ (23). Since the addition of peat to the growing media lowered the $\mathrm{pH}$, the effects of $\mathrm{pH}$ and peat could not be separated. Similarly, Roberts et al. (18) attributed the better germination of American elm (Ulmus americana L.) in potting mix (soil:peat:perlite, 1:2:2) than in sand and soil to the high organic matter content of the potting mix, because it made the benomyl less available to the plants. Plant uptake of benomyl was faster and greater from nutrient solution than from a soil mixture (sandy loam:peat:perlite, 2:1:1) (14) and higher levels of benomyl were needed to prevent ozone injury in pinto beans grown in soil than in those grown in liquid hydroponics (15). Decreased uptake of benomyl and/or its breakdown products is consistent with the increase in pesticide sorption in soils following the application of organic matter (13).

The soil-water partitioning of organic compounds $\left(K_{\mathrm{d}}\right)$ is determined by the fraction of organic matter in the soil and the organic matter-water distribution coeffi- cient $\left(K_{\mathrm{om}}\right) . K_{\mathrm{d}}$ can be estimated from the octanol-water partition coefficient of the chemical $\left(K_{\text {ow }}\right)$, using the following two equations (2):

$$
\begin{array}{cc}
\log K_{\mathrm{om}}=0.52 \log K_{\mathrm{ow}}+0.62 & \text { eq. } 1 \\
K_{\mathrm{d}}=K_{\mathrm{om}}(\% \mathrm{OM} / 100) & \text { eq. } 2
\end{array}
$$

Equation 2 indicates that $K_{\mathrm{d}}$ is linearly related to the percent organic matter $(\mathrm{OM})$ in the soil. The $K_{\text {ow }}$ of benomyl is 132 (7) and the calculated $K_{\mathrm{om}}$ is 53. Trapp and McFarlane (25) classify chemicals as strongly sorbed when $K_{\mathrm{d}}>10$, and moderately sorbed when $1<K_{\mathrm{d}}<10$. This indicates that benomyl will be strongly bound to the soil when the organic matter content is $>19 \%$, and moderately when it is between 1.9 and $19 \%$.

These findings and theoretical considerations led us to hypothesize that phytotoxicity of fungicides in general and Benlate DF in particular is more severe when plants are grown in a medium or soil containing low levels of organic matter. However, there appears to be no published data on the interaction between fungicide phytotoxicity and the composition of the growing medium. Therefore, we conducted two studies to investigate the effect of organic matter on the phytotoxicity of benzimidazole fungicides. The first study concerned the phytotoxicity of different fungicides grown in a medium without organic matter. The second study determined the effect of different levels of organic matter on the phytotoxicity of Benlate DF. Since peat is the most commonly used form of organic matter in growing media for bedding plant production, we varied the amount of peat in the growing media.

\section{MATERIALS AND METHODS}

Plant material. The first study examined fungicide phytotoxicity in a growing medium without organic matter. Petunia 'Ultrapink' seeds were planted and germinated in soilless medium (peat:perlite, 1:1) on 20 January 1995 . Thirty days later they were transplanted, after rinsing the roots, into black plastic flats with a $50 \mathrm{ml}$ cell volume (1,206 flats). The flats were filled with Isolite (size CG-2, Sumimoto Corp., Denver), an inert diatomaceous earth containing no organic matter. Previous studies with Isolite indicated that its low bulk density allows more normal root growth than sand (unpublished data). It consists mainly of $\mathrm{SiO}_{2}(78 \%), \mathrm{Al}_{2} \mathrm{O}_{3}(12 \%)$, and $\mathrm{Fe}_{2} \mathrm{O}_{3}(5 \%)$, has a low cation exchange 
capacity $\left(<0.02 \mathrm{meq} \mathrm{g}^{-1}\right)$, and is chemically inert.

Seeds for the second (organic matter) study were planted in a peat-perlite mixture $(1: 1, \mathrm{vol} / \mathrm{vol})$ on 26 April 1995 and transplanted into 1206 flats on 19 May different sphagnum peat-Isolite mixtures containing (by volume) 100\% Isolite, 95\% Isolite and $5 \%$ peat, $90 \%$ Isolite and $10 \%$ peat, $80 \%$ Isolite and $20 \%$ peat, or $40 \%$ Isolite and $60 \%$ peat (Sunshine peat moss, Sungro Horticulture, Bellevue, WA). Not all the peat-perlite mix was removed from the root systems of the seedlings, to prevent root damage during transplanting. All plant material was grown in a greenhouse until the start of the experiments. Plants were watered with nutrient solution as needed. Plants were not exposed to pesticides prior to the experiments and were transferred to gas exchange chambers in a walk-in growth chamber for the experiments.

Treatments. Three benzimidazole fungicides (Fig. 1) were used to test the toxicity of different benzimidazole fungicides on plants grown in a medium without or1995. Seedlings were transplanted into

ganic matter. Plants were drenched with fungicide solution on 2 March 1995 (41 days after planting). Benlate DF (E.I. du Pont de Nemours \& Co., Wilmington, DE) was applied at either the maximum labeled rate for ornamentals and bedding plants (12 $\mathrm{g} \mathrm{m}^{-2} ; 1.2 \mathrm{~g} \mathrm{~L}^{-1}, 10 \mathrm{~L} \mathrm{~m}^{-2}$ ), or at half the labeled rate $\left(6 \mathrm{~g} \mathrm{~m}^{-2}\right)$. Derosal (Hoechst AG, Frankfurt, Germany) $\left(6.7 \mathrm{~g} \mathrm{~m}^{-2}\right)$ and 3336 WP (W. A. Cleary Chemical Co., Somerset, NJ) (14.9 $\mathrm{g} \mathrm{m}^{-2}$ ) were applied at rates that contained the same molar amount of active ingredient (Fig. 1) as the Benlate DF drenches $\left(0.022 \mathrm{~mol} \mathrm{~m}^{-2}\right)$, close to the maximum labeled rate for 3336 WP. Derosal is not labeled for drenches of bedding plants, but was included because of its chemical similarity to Benlate DF. In the second study, which examined the interaction between organic matter and Benlate DF phytotoxicity, all plants were drenched with the maximum labeled rate of Benlate DF for ornamentals and bedding plants (12 $\mathrm{g} \mathrm{m}^{-2}$ ). Plants were drenched 29 days after planting.

All fungicides were received in original unopened containers and opened in our

\begin{tabular}{llc}
\hline Trade name & active ingredient & $\%$ a.i. \\
\hline Benlate DF & benomyl & 50
\end{tabular}

[methyl 1-(butylcarbamoyl)-2-benzimidazolecarbamate]<smiles>CCCCNC(=O)Nc1nc2ccccc2n1C(N)=O</smiles>

Derosal

carbendazim (MBC)

59

[methyl 2-benzimidazolecarbamate]<smiles>COC(=O)Nc1nc2ccccc2[nH]1</smiles>

3336 WP

thiophanate methyl

[dimethyl 4-4'-o-phenylenebis-3-thioallophanate]

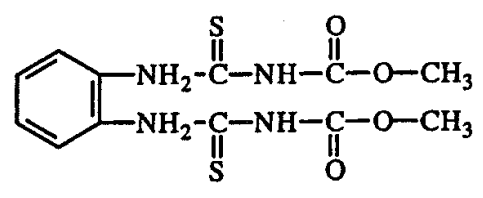

Fig. 1. The trade name, common name of the active ingredient, chemical name, chemical structure, and percent active ingredient (a.i.) of the fungicides used in these studies. laboratory. Benlate DF was stored sealed and desiccated at $4{ }^{\circ} \mathrm{C}$ to prevent chemical changes during storage.

Measurements. Continuous $\mathrm{CO}_{2}$ exchange measurements were made in a tenchamber, open gas exchange system (26). The chambers were located inside a walkin growth chamber, with each chamber containing 60 plants. Each chamber was measured once every $450 \mathrm{~s}$ and daily averages of net photosynthesis $\left(\mathrm{P}_{\text {net }}\right)$ during the light period and respiration $\left(\mathrm{R}_{\text {dark }}\right)$ during the dark period were calculated. $\mathrm{CO}_{2}$ exchange data were also used to determine cumulative carbon gain of the plants throughout the experiment (calculated as the integral of the $\mathrm{CO}_{2}$ exchange rates). Cumulative carbon gain is a useful parameter, because it is closely related to dry matter increase. $\mathrm{CO}_{2}$ exchange measurements were started at least 2 days before the fungicide drenches to confirm pretreatment uniformity of the plant material. Gas exchange data are expressed per unit ground area. Visual differences among the treated plants were evaluated at the end of the experiment. Shoot fresh and dry mass, and water content ([fresh mass - dry mass $]$ /fresh mass) were also determined at the end of both trials. Temperature inside the gas-exchange chambers was maintained at $30 / 25^{\circ} \mathrm{C}$ (day/night), with a relative humidity of 80 to $95 \%$. Photosynthetic photon flux at the canopy level was 800 $\mu \mathrm{mol} \mathrm{m} \mathrm{m}^{-2} \mathrm{~s}^{-1}$ from a 1:1 ratio of high pressure sodium and metal halide lamps. The photoperiod was $14 \mathrm{~h}$, resulting in a daily photon flux of $40 \mathrm{~mol} \mathrm{~m}^{-2} \mathrm{~d}^{-1}$.

The experimental design in both experiments was a randomized complete block with two replications. Data were analyzed by analysis of variance and means were separated using Fisher's least significant difference $e_{0.05}$. Gas exchange data were analyzed separately for each day.

\section{RESULTS AND DISCUSSION}

Phytotoxicity in diatomaceous earth. The experiment with plants in diatomaceous earth indicated that Benlate DF $(1 \times)$ inhibited net photosynthesis (Fig. 2) and cumulative carbon gain (Fig. 3), demonstrating that Benlate DF was phytotoxic. Photosynthetic rates of the Benlate DFtreated plants remained less than $3 \mu \mathrm{mol} \mathrm{m} \mathrm{m}^{-2}$ $\mathrm{s}^{-1}$ during the first two weeks after the drench, while $\mathrm{P}_{\text {net }}$ of control plants increased from 1 to $15 \mu \mathrm{mol} \mathrm{m} \mathrm{m}^{-2} \mathrm{~s}^{-1}$ during this period. The photosynthetic rate of the $1 \times$ Benlate DF-treated plants slowly increased after this 2 -week period, but remained less than $50 \%$ of the control. The effect of $1 \times$ Benlate DF on $\mathrm{P}_{\text {net }}$ was apparent 1 day after the fungicide drench. The $0.5 \times$ Benlate DF treatment decreased $\mathrm{P}_{\text {net }}$ by $50 \%$ at 12 days after the drench and it never completely recovered. 3336 WP decreased $\mathrm{P}_{\text {net }}$ by about $20 \%$ during the first 12 days after the drench, but photosynthetic rates recovered to control levels 
by day 13. Photosynthetic rates following treatment with Derosal were similar to those of control plants. Eventually, the $\mathrm{P}_{\text {net }}$ of Derosal and 3336 WP exceeded that of the control plants, probably because of the increased number of flowers in the control treatment (Table 1), which intercepted some of the light. We previously found that Benlate DF decreased $\mathrm{P}_{\text {net }}$ of petunias in a peat:perlite mixture $(1: 1, \mathrm{vol} / \mathrm{vol})$ by 11 to $25 \%$, while Derosal increased $\mathrm{P}_{\text {net }}$ slightly, and 3336 WP had no effect (26). The effect of Benlate DF on $\mathrm{P}_{\text {net }}$ has been related to its breakdown product DBU $(21,27)$. Although Benlate DF, Derosal, and 3336 WP are chemically similar, only Benlate's active ingredient, benomyl, produces DBU upon breakdown.

Dark respiration was also affected by the fungicide treatments. The $1 \times$ Benlate DF drench resulted in the lowest (closest to zero) $\mathrm{R}_{\text {dark, while the control, Derosal, and }}$ 3336 WP treatments generally had the highest respiration rates. Respiration is often separated into two components, maintenance and growth respiration. Maintenance respiration is related to the size of the plants, while growth respiration is associated with the synthesis of new plant material (3). Both respiration components would be expected to be higher in treatments with the highest carbon gain, because these plants are larger and have higher growth rates. We did indeed find that the faster growing plants (control, Derosal, and $3336 \mathrm{WP}$ ) had higher (more negative) $R_{\text {dark }}$ (Fig. 2).

Total carbon gain at harvest of the plants in the control, Derosal, and 3336 WP treatments was very similar at $13.3 \pm 0.1$ mol m${ }^{-2}$. The $0.5 \times$ Benlate DF treatment decreased total carbon gain by $31 \%$, while the $1 \times$ Benlate DF treatment resulted in a $73 \%$ decrease (Table 1, Fig. 3). Benlate DF reduced total carbon gain of petunia grown in a $1: 1$ peat:perlite mixture by $16 \%$ (26). Thus, Benlate DF is more phytotoxic to petunia grown in Isolite than in a peat:perlite mixture. Similar differences occur with impatiens (unpublished results). There was a close linear correlation between total carbon gain and shoot dry mass $(r=0.998)$. A decrease in plant mass as the result of benomyl applications has been reported for a variety of species $(4,10,16,19,22)$.

The Benlate DF $(1 \times)$-treated plants were very small at the end of the experiment, and $30 \%$ of the plants died. Only one out of the 120 plants drenched with $0.5 \times$ Benlate DF died, but plants were chlorotic and visibly smaller than those in the control treatment. Plants in the control, Derosal, and 3336 WP treatments were much larger, but exhibited some minor interveinal chlorosis. Chlorosis as the result of Derosal and 3336 WP drenches was also reported earlier (26). Benlate DF can also cause chlorosis in several crops $(5,6,10,16,24,28)$.
There were large differences in the number of flowers at the end of the trial. Both Benlate DF treatments and 3336 WP significantly reduced the number of flowers (Table 1). Benlate DF drenches (but not $3336 \mathrm{WP}$ ) also slightly reduced flowering of petunia and impatiens in peat/perlite media (26).

Organic matter and phytotoxicity. Growth of Benlate DF treated plants was highly dependent on the amount of organic matter in the growing medium. Net photosynthesis in the $0 \%$ OM treatment did not significantly increase until 11 days after the Benlate DF drench (Fig. 4), while $\mathrm{P}_{\text {net }}$ in all the other treatments increased continuously. Differences in $\mathrm{P}_{\text {net }}$ among the other four treatments did not become apparent until the fifth day after the drench. Photosynthesis was clearly related to the

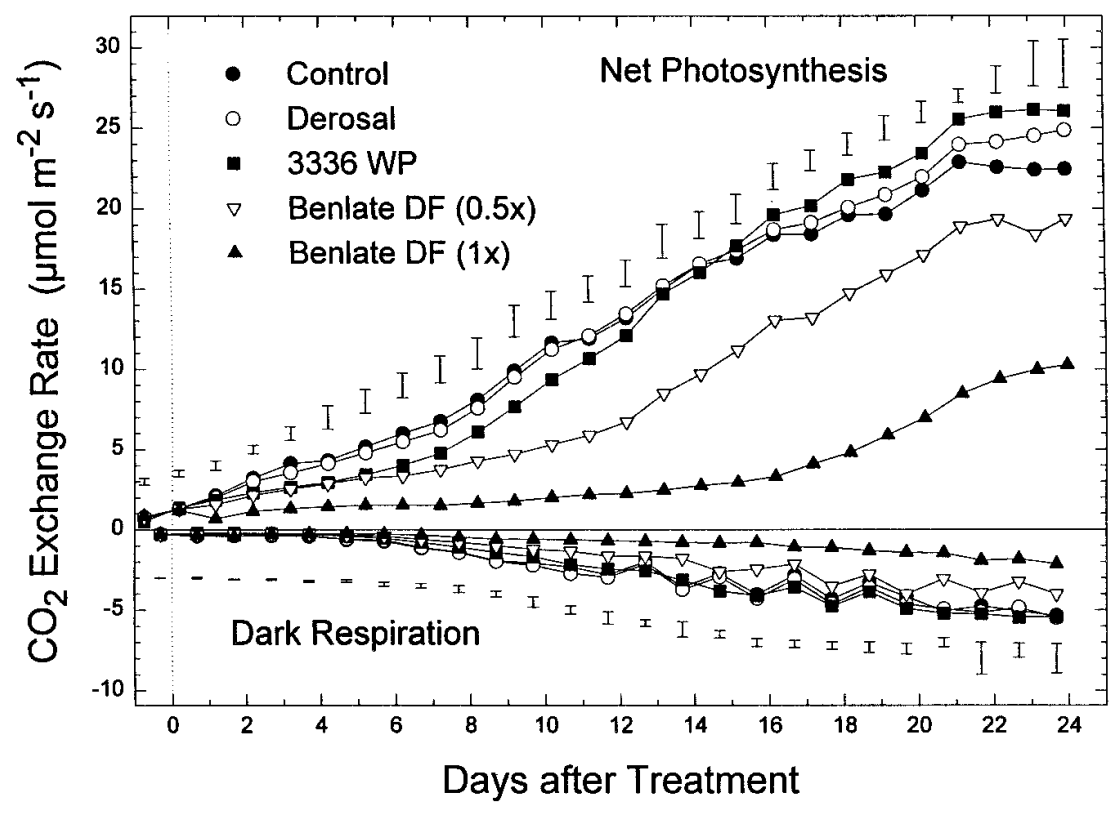

Fig. 2. The effect of different benzimidazole fungicides on the net photosynthesis and dark respiration rate of a petunia crop. Plants were grown in diatomaceous earth and drenched with fungicide on day zero. All treatments contained active ingredient at a rate of $0.022 \mathrm{~mol} \mathrm{~m}^{-2}$, except for the 0.5 Benlate DF treatment $\left(0.011 \mathrm{~mol} \mathrm{~m}^{-2}\right)$. Error bars represent the $\mathrm{LSD}_{0.05}$ to compare treatments within a day.

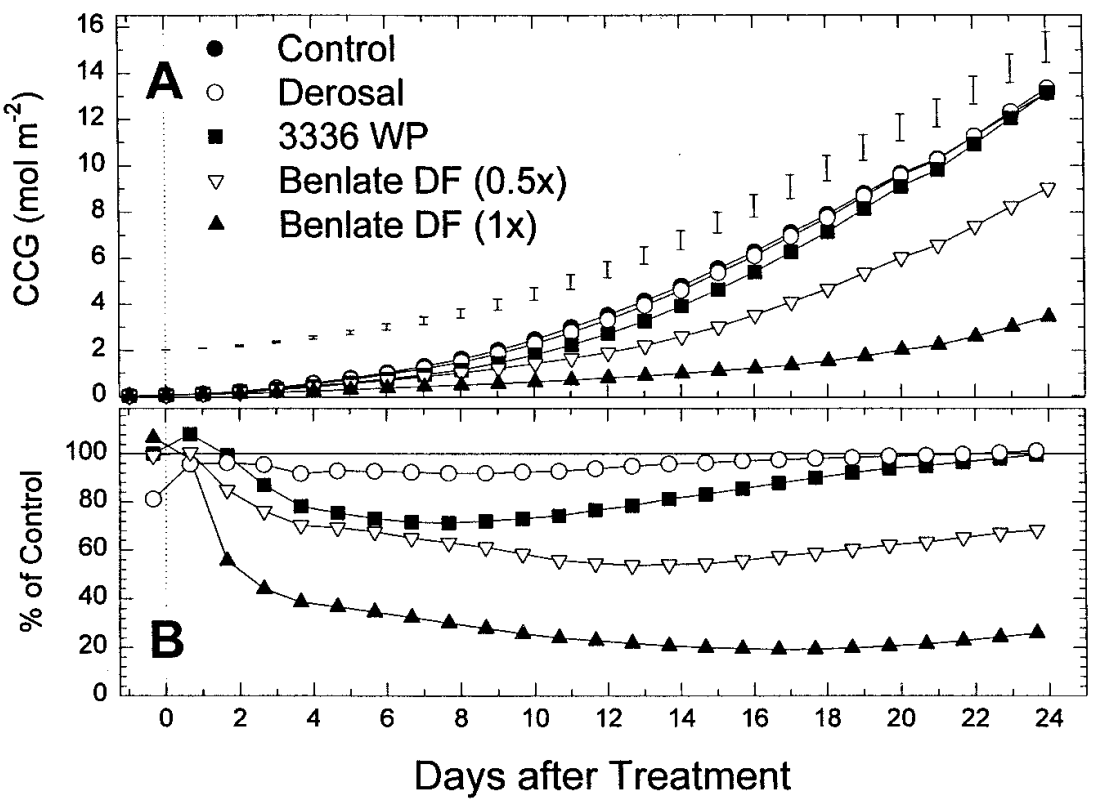

Fig. 3. (A) Cumulative carbon gain (CCG) of a petunia crop as affected by different benzimidazole fungicides. (B) Cumulative carbon gain expressed as a percentage of the cumulative carbon gain of the control treatment. Plants were grown in diatomaceous earth and fungicide treatments were started on day zero. The active ingredient was applied at a rate of $0.022 \mathrm{~mol} \mathrm{~m}^{-2}$ in all treatments except the $0.5 \times$ Benlate DF treatment $\left(0.011 \mathrm{~mol} \mathrm{~m}^{-2}\right)$. 
organic matter content of the growing medium. Increased organic matter resulted in higher $\mathrm{P}_{\text {net }}$. Dark respiration was also affected by the treatments (Fig. 4). Respiration increased with increased amounts of organic matter in the growing medium, presumably because the larger and faster growing plants had higher growth and maintenance respiration rates.

The relative differences in $\mathrm{CO}_{2}$ exchange rates were generally reflected in shoot fresh and dry mass. The correlation between shoot dry mass and total carbon gain was highly significant (shoot dry mass $=0.43+3.08 \times$ total carbon gain, $r^{2}=$ 0.98). Shoot dry mass in the $20 \%$ OM treatment was slightly higher than expected from its total carbon gain and was similar to that in the $60 \%$ OM treatment (Table 2). A visual examination of the roots of the plants indicated that plants grown in $60 \%$ $\mathrm{OM}$ had larger root systems than those in 20\% OM (Fig. 5), which can explain the difference in total carbon gain between these treatments. Low amounts of organic matter significantly reduced the water content of the plants (Table 2), perhaps

Table 1. The effect of different fungicides on the growth and flowering of petunia, grown in diatomaceous earth

\begin{tabular}{lccc}
\hline Fungicide & $\begin{array}{c}\text { Shoot dry mass } \\
\left(\mathbf{g ~ p l a n t ~}^{-1}\right)\end{array}$ & $\begin{array}{c}\text { Total carbon gain } \\
\left(\mathbf{m o l ~ m}^{-\mathbf{2}}\right)\end{array}$ & $\begin{array}{c}\text { Flowers } \\
(\# / 60 \text { plants })\end{array}$ \\
\hline Control & $0.545 \mathrm{a}^{\mathrm{z}}$ & $13.2 \mathrm{a}$ & $32.5 \mathrm{a}$ \\
Derosal & $0.565 \mathrm{a}$ & $13.4 \mathrm{a}$ & $18.5 \mathrm{ab}$ \\
$3336 \mathrm{WP}$ & $0.537 \mathrm{a}$ & $13.2 \mathrm{a}$ & $12.0 \mathrm{bc}$ \\
Benlate DF $(0.5 \times)$ & $0.345 \mathrm{~b}$ & $9.1 \mathrm{~b}$ & $7.5 \mathrm{bc}$ \\
Benlate DF $(1 \times)$ & $0.113 \mathrm{c}$ & $3.5 \mathrm{c}$ & $0.5 \mathrm{c}$ \\
\hline
\end{tabular}

${ }^{\mathrm{y}}$ Active ingredient of the fungicides was applied at a rate of $0.022 \mathrm{~mol} \mathrm{~m}^{-2}$, except for the $0.5 \times$ Benlate DF treatment $\left(0.011 \mathrm{~mol} \mathrm{~m}^{-2}\right)$. Plants were harvested 25 days after the fungicide drench.

${ }^{\mathrm{z}}$ Mean separation by Fisher's protected least significant difference $(P=0.05)$.

Table 2. The effect of different levels of organic matter in the growing medium on the growth of Benlate DF-treated plants, which were harvested 13 days after the drench

\begin{tabular}{lllll}
\hline Organic matter & $\begin{array}{c}\text { Shoot fresh mass } \\
\left(\mathbf{g ~ p l a n t ~}^{\mathbf{1}}\right)\end{array}$ & $\begin{array}{c}\text { Shoot dry mass } \\
\left(\mathbf{g ~ p l a n t}^{\mathbf{1}}\right)\end{array}$ & $\begin{array}{c}\text { Water content } \\
(\boldsymbol{\%})\end{array}$ & $\begin{array}{c}\text { Total carbon gain } \\
\left(\mathbf{m o l ~ m}^{-2}\right)\end{array}$ \\
\hline $0 \%$ & $0.52 \mathrm{~d}^{\mathrm{z}}$ & $0.078 \mathrm{~d}$ & $84.9 \mathrm{~d}$ & $1.26 \mathrm{e}$ \\
$5 \%$ & $1.53 \mathrm{c}$ & $0.184 \mathrm{c}$ & $88.0 \mathrm{c}$ & $3.63 \mathrm{~d}$ \\
$10 \%$ & $2.65 \mathrm{~b}$ & $0.234 \mathrm{~b}$ & $91.1 \mathrm{~b}$ & $4.52 \mathrm{c}$ \\
$20 \%$ & $4.20 \mathrm{a}$ & $0.288 \mathrm{a}$ & $93.1 \mathrm{a}$ & $5.06 \mathrm{~b}$ \\
$60 \%$ & $4.00 \mathrm{a}$ & $0.295 \mathrm{a}$ & $92.6 \mathrm{ab}$ & $5.86 \mathrm{a}$ \\
\hline
\end{tabular}

${ }^{\mathrm{z}}$ Mean separation by Fisher's protected least significant difference $(P=0.05)$.

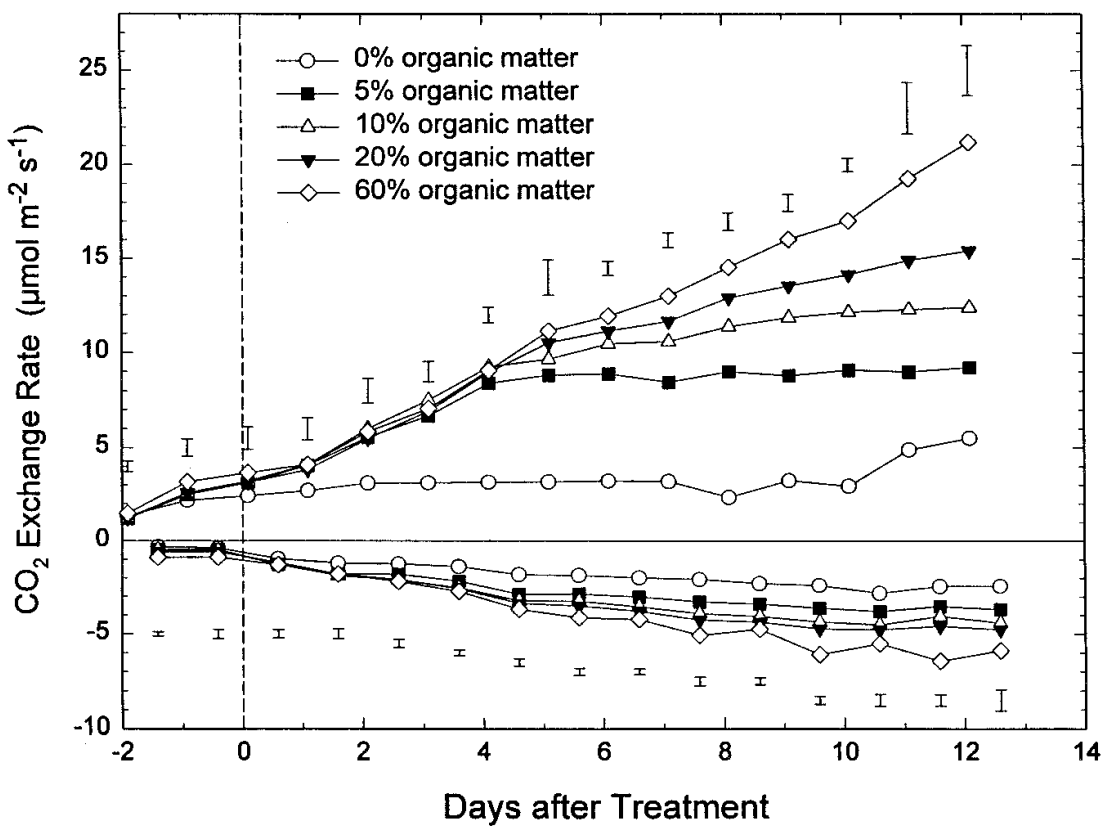

Fig. 4. Net photosynthesis and dark respiration of petunia grown in soilless media with different mixtures of diatomaceous earth and organic matter (peat moss). All plants were drenched with Benlate $\mathrm{DF}$ at a rate of $1.2 \mathrm{~g} \mathrm{~m}^{-2}$ on day zero. Error bars represent the $\mathrm{LSD}_{0.05}$ to compare treatments within a day. because of the increased occurrence of necrosis.

Although some of the treatment differences in this study may have been caused by differences in the growing media, it seems unlikely that this was an important factor. We have compared plant growth in peat-perlite mixtures and Isolite and growth was identical (unpublished results). This is also clear from the growth rate of the control plants grown in diatomaceous earth. These plants reached photosynthetic rates of $26 \mu \mathrm{mol} \mathrm{m} \mathrm{m}^{-2} \mathrm{~s}^{-1}$ (Fig. 2), which was higher than that of any of the Benlate DFtreated plants in the organic matter study (Fig. 4). We therefore conclude that the differences in $\mathrm{P}_{\text {net }}$ in this study were the result of increased Benlate DF phytotoxicity with decreased organic matter in the growing medium.

The amount of organic matter in the medium not only affected $\mathrm{P}_{\text {net }}$, but also influenced plant appearance. Plants grown in $0 \% \mathrm{OM}$ and drenched with Benlate $\mathrm{DF}$ were severely chlorotic, and the severity of the chlorosis decreased as the amount of organic matter increased. Differences in plant size were obvious among the $0,5,10$, and $20 \%$ OM treatments, while shoots from the 20 and $60 \% \mathrm{OM}$ were of similar size (Fig. 5). However, plants in the $20 \%$ OM treatment were much more chlorotic than plants in 60\% OM, which showed only minor interveinal chlorosis and had dark green leaves. Plants were harvested before extensive flowering occurred, so differences in flowering could not be determined.

Reduced phytotoxicity of Benlate DF with increased amounts of organic matter in the growing medium agrees with the results of Schreiber and Hock (22), who found that fungitoxicant uptake of benomyl-treated plants was highest in media with less organic matter. Roberts et al. (18) and Hoestra (9) suggested that organic material makes benomyl less available for plant uptake, which is supported by the dependence of $K_{\mathrm{d}}$ on organic matter content of the soil. Benomyl is relatively immobile in soil $(1,11,17)$ and benomyl and/or its breakdown products are probably bound by organic matter in the soil or growing medium. Immobilization of pesticides by organic material in soils is common (13), and decreased bioavailability of pesticides may at least partially be due to the binding to high molecular weight humic substances (20). Humic acid, for example, can inactivate benomyl (12). The label rate of many soil-applied pesticides depends on the amount of organic matter in the soil, presumably, because the organic matter content affects the efficacy of the pesticide. However, the recommended application rate for Benlate DF drenches is independent of the growing medium.

Interactions between Benlate DF and organic material probably account for the reduced Benlate DF phytotoxicity in media 


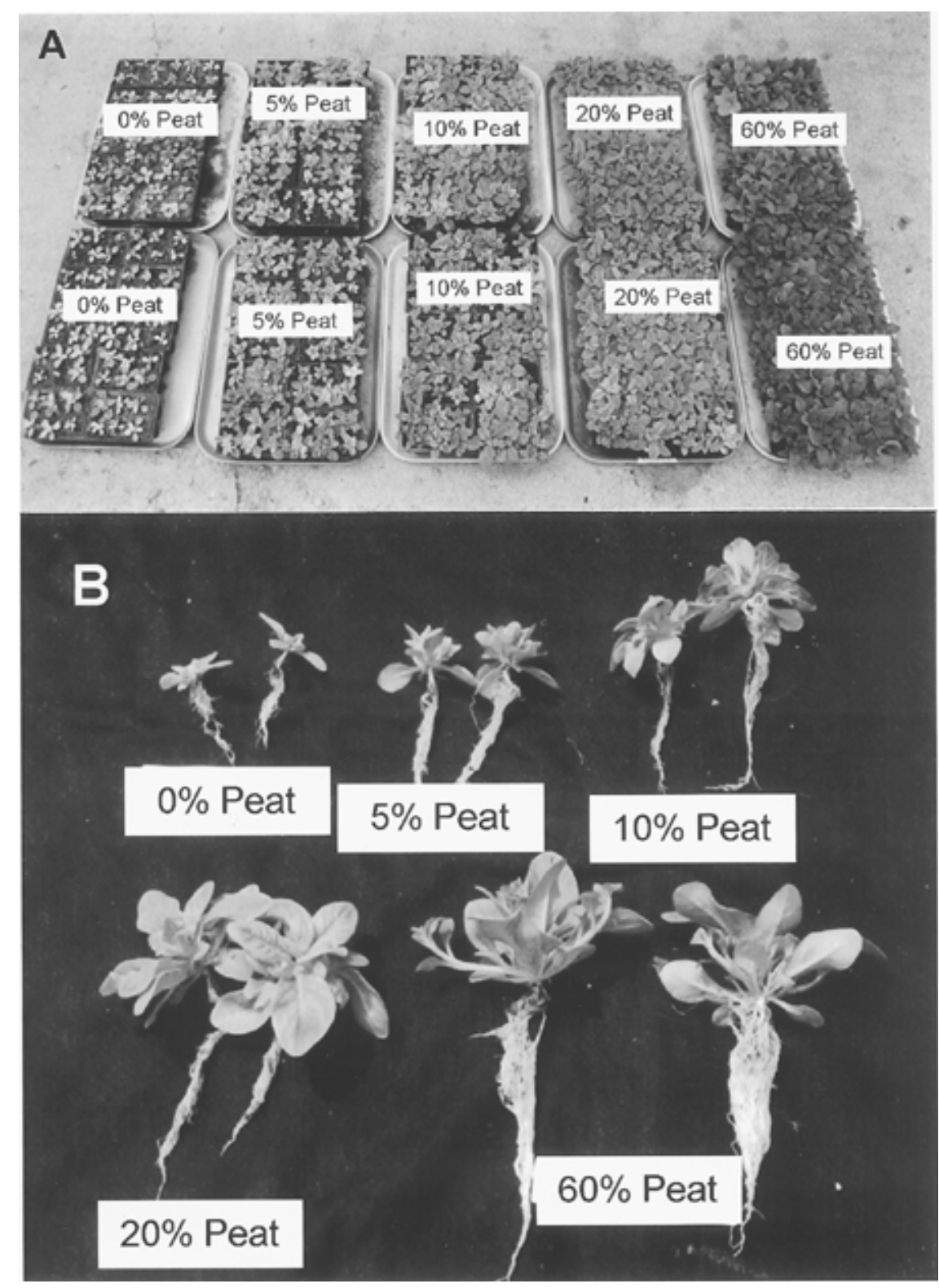

Fig. 5. Trays (A) and individual plants (B) grown in different mixtures of organic material (peat) and diatomaceous earth (Isolite). Plants were drenched with Benlate DF 6 days after transplant and harvested 19 days after transplant. Benlate DF phytotoxicity was more severe when the growing medium contained less peat. Note the difference in the size of the root systems between the 20 and $60 \%$ organic matter treatments.

with high organic matter in this study. Based on $K_{\mathrm{d}}$ calculations, solution levels of benomyl would decrease with increases in organic matter in the medium. Other factors that may have affected Benlate DF phytotoxicity are differences in $\mathrm{pH}$ and microbial activity in growing medium. It is possible that $\mathrm{pH}$ affects DBU formation and breakdown, while microbial activity could possibly aid in the breakdown of phytotoxic compounds. Microbial activity most likely increased with increasing amounts of peat, while this decreased the $\mathrm{pH}$ of the growing medium.

In summary, Benlate DF reduced photosynthesis of plants growing in diatomaceous earth by $70 \%$ and delayed flowering. Phytotoxicity of Benlate DF was dramatically reduced by adding up to $60 \%$ OM in

\section{ACKNOWLEDGMENTS}

This research was supported by the Utah Agricultural Experiment Station, Utah State University, Logan 84322-4820. We thank D. Knight and G. Koerner for technical assistance, and H. Deer, P. Grossl, S. Thompson, and J. White for their critical reviews of this manuscript.

\section{LITERATURE CITED}

1. Baude, F. J., Pease, H. L., and Holt, R. F. 1974. Fate of benomyl on field soil and turf. J. Agric. Food Chem. 22:413-418.

2. Briggs, G. G. 1981. Theoretical and experimental relationships between soil adsorption octanol-water partition coefficients, water solubilities, bioconcentration factors and the parachor. J. Agric. Food Chem. 29:1050-1059.

3. Charles-Edwards, D. A., Doley, D., and Rimmington G. M. 1986. Modeling plant growth and development. Academic Press.

4. Cole, H., Boyle, J. S., and Smith, C. B. 1970. Effect of benomyl and certain cucumber viruses on growth, powdery mildew, and element accumulation by cucumber plants in the greenhouse. Plant Dis. Rep. 54:141-145.

5. Delp, C. J., and Klopping, H. L. 1968. Performance attributes of a new fungicide and mite ovicide candidate. Plant Dis. Rep. 52:9599.

6. Hammett, K. R. W. 1968. Root applications of a systemic fungicide for control of powdery mildews. Plant Dis. Rep. 52:754-758.

7. Hansch, C., and Leo., A. 1985. MEDCHEM project. Version 26. Pomona College, Claremont, CA.

8. Hock, W. K., Schreiber, L. R., and Roberts, B. R. 1970. Factors influencing uptake, concentration, and persistence of benomyl in American elm seedlings. Phytopathology 60:16191622 .

9. Hoestra, H. 1976. Effect of benomyl on the potato cyst nematode, Heterodera rostochiensis. Neth. J. Plant Pathol. 82:17-23.

10. Ishii, M. 1973. Control of powdery mildew of cassia occidentalis in relation to bioassay of cymbidium mosaic virus. Plant Dis. Rep. 57:475-477.

11. Johnson, W. G., and Lavy, T. L. 1994. In situ dissipation of benomyl, carbofuran, and triclopyr at three soil depths. J. Environ. Qual. 23:556-562.

12. Kataria, H. R., and Sunder S. 1987. Fungicidal control of Rhizoctonia solani in relation to soil texture, organic matter and clay minerals. Ann. Appl. Biol. 110:43-51

13. Martinez-Inigo, M. J., and Almendros, G. 1992. Pesticide sorption on soils treated with evergreen oak biomass on soils treated with evergreen oak biomass at different humification stages. Commun. Soil Sci. Plant Anal., 23:1717-1729.

14. Pellissier, M., Lacasse, N. L., and Cole, $\mathrm{H}$. 1971a. Uptake of benomyl by bean plants. Phytopathology 61:132.

15. Pellissier, M., Lacasse, N. L., and Cole, $\mathrm{H}$. 1971b. Effect of benomyl on the response to ozone in Pinto beans. Phytopathology 61:131132.

16. Reyes, A. A. 1975. Phytotoxicity of benomyl to crucifers. Phytopathology 65:535-539.

17. Rhodes, R. C., and Long, J. D. 1974. Run-off and mobility studies on benomyl in soils and turf. Bull. Environ. Contam. Toxicol. 12:385393.

18. Roberts, B. R., Hock, W. K, and Schreiber, L. R. 1973. The effect of benomyl on the growth of American elm seedlings. Phytopathology 63:85-87.

19. Rouchaud, J., Moons, C., and Meyer, J. A. 1985. The effects of herbicide and fungicide treatments on the growth and provitamin A content of lettuce. Pestic. Sci. 16:88-92.

20. Scheunert, I., Mansour, M., and Andreux, F. 
1992. Binding of organic pollutants to soil organic matter. Int. J. Environ. Anal. Chem. 46:189-199.

21. Schilling, D. G., Aldrich, H. C., Moye, H. A, Gaffney, J. F., Tolson, J. K., Querns, R., Mossler, M. A., and Russell, B. L. 1994. $N, N^{\prime}$-dibutylurea from $n$-butyl isocyanate, a degradation product of benomyl. 2. Effects on plant growth and physiology. J. Agric. Food. Chem. 42:1209-1212.

22. Schreiber, L. R., and Hock, W. K. 1975. Effects of benomyl and thiabendazole on growth of several plant species. J. Am. Soc. Hortic. Sci. 100:309-313.

23. Schreiber, L. R., Hock, W. K., and Roberts, B.
R. 1971. Influence of planting media and soil sterilization on the uptake of benomyl by American elm seedlings. Phytopathology 61:1512-1515.

24. Schroeder, W. T., and Provvidenti, R. 1968. Systemic control of powdery mildew on cucurbits with fungicide 1991 applied as soil drenches and seed treatments. Plant Dis. Rep. 52:630-632.

25. Trapp, S., and McFarlane, J. C. Plant contamination. Modeling and simulation of organic chemical processes. Lewis Publishers, FL.

26. van Iersel, M. W., and Bugbee, B. 1996. Phytotoxic effects of benzimidazole fungi- cides on bedding plants. J. Am. Soc. Hortic. Sci. 121:1095-1102.

27. van Iersel, M. W., and Bugbee, B. 1997 Dibutylurea reduces photosynthesis, growth, and flowering of petunia and impatiens. In press.

28. Wensley, R. N. 1972. Effects of benomyl and two related systemic fungicides on growth of fusarium wilt-susceptible and resistan muskmelon. Can. J. Plant Sci. 52:775-779.

29. Zaronsky, C., and Stipes, R. J. 1969. Some effects on growth and translocation of thiabendazole and methyl 1-(butylcarbamoyl)-2benzimidazolecarbamate applied to Ulmus americana seedlings. Phytopathology 59:1562. 